\title{
Judgment Capacities of the Actor and the Spectator in Hannah Arendt's Theory of Judgment
}

\author{
Özge Çelik* \\ Gazi University
}

\begin{abstract}
The argument has been made that in her later works Arendt finally subsumes judging as a thinking activity under the vita contemplativa rather than as part of action in the vita activa. This article argues against this interpretation of Arendt's unfinished theory of judgment defended specifically by Ronald Beiner and Richard Bernstein. Judgment as representative and imaginative thinking remains part of the vita activa because, as distinct from philosophical thinking that is solitary, judgment is communal. Judgment always depends upon the presence of others in a particular public sphere, and in the act of judging an individual is actually engaged in creating a community of those judging. The judgment capacities of the actor and the spectator have a complementary function in preserving plurality in the public realm, and, as such, they are part of the vita activa.
\end{abstract} Key words: Arendt, judgment, actor, spectator, plurality.

\section{Hannah Arendt'in Yargı Teorisinde Aktör ve İzleyicinin Yargı Kapasiteleri}

\section{Özet}

$\mathrm{Bu}$ makalede Ronald Beiner ve Richard Bernstein tarafından öne sürülen, Arendt'in son dönem eserlerinde yargılamayı eylemin bir parçası olarak vita activa'nın içerisinde değerlendirmekten ziyade düşünsel etkinlik olarak vita contemplativa'nın altında sınıflandırdığı savı eleştirilmektedir. Temsili ve imgesel düşünme biçimi olarak yargı, vita activa' 'n içerisinde kalmaya devam etmektedir; çünkü yalnızlık gerektiren felsefi düşünmeden farklı olarak yargı, kendinden başkalarıyla birarada olmayı gerektirmektedir. Yargı, her zaman belirli bir kamusal alandaki başkalarının varlığınına bağlıdır ve yargılama eylemini gerçekleştiren birey aslında yargılayanlardan oluşan bir topluluğunun yaratılmasına dahil olmaktadır. Aktör ve izleyicinin yargı kapasiteleri, kamusal alandaki çoğulluğun muhafaza edilmesinde birbirlerini tamamlayıı işlev görürler ve bu nedenle her ikisi de vita activa'ın parçasıdır.

Anahtar kelimeler: Arendt, yargl, çŏ̆ulluk, aktör, izleyici.

* Dr. Özge Çelik is a researcher in the Department of Public Administration at Gazi University, Beşevler, Çankaya, 06500, Ankara, Turkey E-mail: ozge.celik@colorado.edu. 
$\mathrm{H}$ annah Arendt is one of the most original and influential thinkers of the $20^{\text {th }}$ century and her ideas have inspired scholars across different disciplines. For her, "problems of political participation and civic agency occupied the center stage," and so long as we continue to explore the ways in which democracy can face the challenges of globalization, diversity, political apathy, and government control Arendt will remain with us in the $21^{\text {st }}$ century (Isaac, 1997: 74). Yet we can believe with Steinberger that "her work raises nearly as many questions as it answers" (1990: 816). Therefore, Arendt's political thought is also kept alive by the critical commentary on her work, some of which raises questions about the coherence of her ideas (Mewes, 2009: 15). Two of the commentators on Arendt's theory of judgment, Ronald Beiner and Richard Bernstein, observe an important shift in Arendt's formulation of judgment from 1961, when she published $B e$ tween Past and Future, to 1970 when she lectured on Kant's political philosophy at the New School (Beiner, 1994; Bernstein, 1986). Arendt's earlier formulation of judging as a specifically political ability contradicts her later formulation of it as the contemplative activity of a solitary spectator retrospectively bestowing meaning upon past events. This shift, Bernstein argues, reveals a conflict between Arendt's two central concerns, acting and thinking. While one strain in her thought associates judgment with debate and opinion formation in the public sphere, another associates it with the contemplative activity that deals with the past. In the first formulation, judgment is located within the vita activa though later it becomes part of the vita contemplativa (Bernstein, 1986). Similarly, Beiner argues, Arendt defines judgment as a "function of representative thinking and enlarged mentality of political actors" in her early works, but she emphasizes "the contemplative and disinterested dimension of judgment, which operates retrospectively" in her later works. For Beiner, Arendt finally achieves consistency by "opting wholly for the latter conception of judgment" and placing judgment as such "exclusively within the ambit of the vita contemplativa or the life of the mind" (Beiner, 1994: 379-380).

This article argues against Beiner's and Bernstein's claim that the tension in Arendt's theory of judgment represents a shift from the vita activa to the vita contemplativa as her central focus and preoccupation. Either as a capacity of the engaged actor or of the disinterested and uninvolved spectator, judging always belongs to the world of appearances, which is the idea that constitutes Arendt's political ontology, and remains deeply rooted in the human condition of plurality. Therefore, this article argues that the proper location of judgment is as part of the vita activa rather than the vita contemplativa.

The first section sets out and critically analyzes Beiner's and Bernstein's claims about Arendt's theory of judgment. It calls our attention to the problems raised by their accounts where judging is theorized as the prerogative of the solitary contemplating spectator. The second section examines Arendt's ontology of politics as appearance and the theatrical structure of the public realm in her political thought. It argues that the judgment of the engaged actor and the disinterested spectator do not represent mutually exclusive and fixed roles in the public sphere. The third section analyzes the relation between judgment, freedom, and plurality. It argues with Zerilli that plurality confronts us as a political relation that is actualized and sustained by judgment's function in affirming the freedom in action. The fourth section analyzes the judgment capacity of the 
engaged actor as the formation and testing of opinions through intersubjective dialogue and persuasion within a public sphere. The fourth section discusses the judgment capacity of the disinterested spectator. It argues that the judging of the spectator is essential for preserving plurality in the public sphere and, therefore, it does not supplant but supports the role of the judging and performing actor.

\section{The Solitary Contemplating Spectator: Beiner and Bernstein on Arendt's Theory of Judgment}

Arendt's 1961 essays The Crisis in Culture and Truth and Politics, along with her 1970 Lectures on Kant's Political Philosophy, constitute the main sources for her unfinished theory of judgment. ${ }^{[1]}$ In the former two, Arendt focuses on the role of judgment in opinion formation and debate in the public sphere. She calls judging "a specifically political ability," and defines the mode of thinking that is active in judging as a political way of thinking (Arendt, 1993: 221). This political way of thinking enables one to consider "a given issue from different viewpoints" by representing or making present in the judging person's mind the standpoints of others (Arendt, 1993: 241). Arendt's emphasis on the political character of judgment in The Crisis in Culture and Truth and Politics lead her commentators to conclude that she formulates judgment as a political capacity of the actors in her earlier works. Beiner writes, "in her earlier formulations we find discussions of the relation of judgment to 'representative thinking' and opinion, leading one to think that judgment is a faculty exercised by actors in political deliberation and action" (1994: 379). Similarly, for Bernstein, in Arendt's earlier works, "all the paths of her thinking lead us to the centrality and distinctiveness of the human capacity to judge" in politics (1986: 230). Beiner and Bernstein argue that Arendt's later formulation of judgment, specifically in her Lectures on Kant's Political Philosophy, contradicts this earlier analysis. Judgment, as Arendt defines it in $L K P P$, is a mental capacity primarily of the spectators who refrain from political action, and it requires disinterestedness or impartiality, achieved through the functioning of imagination and reflection. This later formulation leads Arendt's commentators to claim that she had changed her previous position on the issue and, under the influence of Kant, situated judgment in the inner realm of mind as a mental faculty almost independent of the realm of politics.

In Beiner's view, the tension between Arendt's earlier and later formulations of judgment is that:

On the one hand, Arendt is tempted to integrate judgment into the vita activa, seeing it as a function of the representative thinking and enlarged mentality of political actors, exchanging opinions in public while engaged in common deliberation. On the other hand, Arendt wants to emphasize the contemplative and disinterested dimension of judgment, which operates retrospectively, in analogy to aesthetic judgment. Judgment in the latter sense is placed exclusively within the ambit of the vita contemplativa or life of the mind (1994: 379).

[1] Arendt died right after completing the volume on thinking in The Life of the Mind and before writing the volume on judging. 
For Beiner, the actors engaged in political deliberation are non-solitary and, in exercising their capacity for representative thinking and enlarged mentality, they do not withdraw themselves from the actual doings of others, while the spectator is solitary and disinterested by virtue of her non-participation in political deliberation. Thus Beiner juxtaposes "the solitary (though public-spirited) contemplator" against "the actor (whose activity is necessarily non-solitary)" and maintains that "one acts with others, one judges by oneself (albeit, by making present in one's imagination those who are absent)" (1994: 386). Beiner is quite right in that one acts with others but judges by oneself. Yet contrary to his claim, exercised by either the actor or the spectator, judgment requires disinterestedness and representative thinking. For Arendt, the only condition for the operation of the judging actor's representative way of thinking is disinterestedness (1993: 242). Similarly, the uninvolved spectator is still required to think representatively in order to obtain the proper impartiality required for judging.

In The Crisis in Culture, Arendt explains judging as a political way of thinking in reference to Kant's notion of enlarged mentality, and as such differentiates it from "the thought process of pure reasoning" which involves an inner dialogue "between me and myself" (Arendt, 1993: 220). The enlarged way of thinking involves "an anticipated communication with others" with whom the judging person "must finally come to some agreement" (Arendt, 1993: 220). In Truth and Politics, Arendt explains that the enlarged way of thinking active in judging requires representation of the standpoints of others. The "process of representation does not blindly adopt the actual views of those who stand somewhere else;" rather it is a question of "being and thinking in my own identity where actually I am not" (Arendt, 1993: 241). This process of representative thinking is an "exertion of the imagination" and the only condition for its operation is disinterestedness, that is, "liberation from one's private interests" (Arendt, 1993: 241242). Similarly, in $L K P P$, judgment requires disinterestedness achieved through the functioning of imagination, representation, and reflection. Imagination "makes present what is absent, transforms the objects of the objective senses into 'sensed' objects" and it does this by means of representation (Arendt, 1992: 65). Imagination prepares the object of judgment for the operation of reflection because what affects one only in representation, and not by its immediate presence, is a proper object of approbation and disapprobation. Arendt claims that it is "by means of representation" that "the proper distance, the remoteness or uninvolvedness or disinterestedness, that is prerequisite for approbation and disapprobation, for evaluating something at its proper worth" is established (1992: 67). Arendt explains that, in Kant's thinking, disinterestedness is an attribute of the spectator and not that of the actor, because the spectator withdraws from direct involvement in the events to a general standpoint outside the game. The uninvolved spectator occupies this general standpoint only if she is able to obtain impartiality "by taking the viewpoints of others into account," that is, by thinking in an enlarged way that "by force of imagination ... makes the others present and thus moves in a place that is potentially public" (Arendt, 1992: 43). Arendt's emphasis on the role of disinterestedness, enlarged mentality, and representative thinking in the operation of the faculty of judgment in the earlier as well as the later formulation runs against the distinction 
Beiner establishes between the solitary spectator and the non-solitary actor. Both the actor and the spectator are alone in making up their minds while judging, and yet both reproduce a potential public realm in their minds by representing the positions of others.

Furthermore, in both the earlier and the later formulations, the judging person is not in complete solitude. The judging actor needs the presence of others so that she can think in their place for the purpose of coming to a potential agreement with them. The actor's judgment derives its specific validity from a potential agreement with others. Similarly, the uninvolved spectator's thinking is required to be enlarged and representative because "the test of free and open examination" or "general communicability" is the condition of her judgment's validity (Arendt, 1992: 40). More importantly, in LKPP Arendt maintains that "the public realm is constituted by the critics and spectators," and although she is not involved in political action, "the spectator ... is always involved with other fellow spectators" (1992: 63). Arendt's claim that "spectators exist only in the plural" alludes to the essential political character of judgment: its need for and orientation towards others who also judge (1992: 63). Given this political dimension of even the judgment of the spectator, it is hard to believe, with Beiner, that Arendt has finally achieved consistency by "opting wholly" for the later formulation where judgment is confined to "the vita contemplativa, - a sphere of human life which Arendt conceived to be by definition, solitary, exercised in withdrawal from the world and from other men" (1994: 379).

Bernstein offers a more nuanced analysis of Arendt's theory of judgment by claiming that "in the latest characterizations of judgment she continued to emphasize its essential political character." However, he also maintains that in her later formulation:

Arendt herself emphasizes, judging is the capacity of the spectator who views and judges human affairs, the human spectacle, not that of the actors who participate. This does seem flagrantly to contradict the claim that judging is a form of action - debate - which Arendt takes to be the of essence politics (1986: 231, emphasis added).

Bernstein regards the spectator in the singular most of the time, while considering the participating actors in the plural and, by definition, non-solitary. For him, in Arendt's earlier formulation, judgment is a part of the opinion formation process in the public realm and "not a private activity performed by a solitary thinker." Rather it "requires a political community of equals, the imagination to represent other viewpoints, and the courage to submit opinions to public exposure and test" (Bernstein, 1986: 228).

By depicting judgment as the capacity of a solitary contemplating spectator in Arendt's later formulation, Beiner and Bernstein render the judging spectator indistinguishable from the thinking individual in The Life of the Mind. The judging spectator never leaves the realm of appearances and plurality, while the thinking individual is one who "deals with invisibles" in "the soundless dialogue" of the "two-in-one" (Arendt, 2003a: 189). The thinking individual engages in a dialogue with herself as if she is two selves within one, and agreement between these two selves is the fundamental rule of thinking (Arendt, 1990: 85-90). In Beiner's and Bernstein's accounts, like the thinking individual, the solitary spectator takes flight to this realm of solitude, as though judg- 
ing is limited to an inner dialogue within the self. Beiner's and Bernstein's readings of spectatorship in Arendt's theory of judgment resonate with Arendt's citation of a parable ascribed to Pythagoras:

Life ... is like a festival; just as some come to the festival to compete, some to ply their trade, but the best people come as spectators [theatai], so in life the slavish men go hunting for fame [doxa] or gain, the philosophers for truth (1992: 55).

For Arendt, the idea underlining this parable is "the supremacy of the spectator's way of life, the bios theōrētikos (from theōrein, 'to look at')" (1992: 55). However, Arendt views this parable as an example of the philosophers' view of the realm of human affairs. For her, in the philosophical tradition, "the contemplative way of life presupposes withdrawal from the many; it singularizes one, as it were, because contemplation is a solitary business or, at least, can be carried on in solitude" (Arendt, 1992: 59, emphasis added). Arendt argues that "one can never speak, as Pythagoras did" of "the spectator" (1992: 63). Contrary to Beiner's and Bernstein's arguments, Arendt asserts that, although "the spectator is not involved in the act," she is "always involved with other fellow spectators" with whom she constitutes a critical public (1992: 63). Hence, Arendt agrees with Kant in that what constituted the "appropriate public realm" for the French Revolution was the "acclaiming spectators" (1992: 61).

Inaccurately considering judging as the contemplative capacity of the solitary and removed spectator in Arendt's later works also has consequences for our wider understanding of key concepts like "plurality" and "appearance" in her political thought. First, the idea of a solitary contemplating spectator contradicts Arendt's idea that spectators always exist in the plural. Plurality has a special meaning for Arendt. The idea that spectators exist in the plural signifies that each spectator has a different viewpoint on a given issue and, her judgment would therefore not be identical with the judgments of other spectators. This difference in viewpoints is not a mere difference of subjectively held beliefs; rather it is characteristic of the essential manifoldness of the realm of human affairs that provides politics with its unique character. By publicly communicating her judgment to the other spectators, each spectator inserts herself into a web of relationships between spectators. Within this web of relationships, judgment cannot be the contemplative activity of solitary individuals because, as it is immersed in a web of judgments of other spectators, judgment can be understood properly only as the outcome of a continuous forming and reforming of opinions on a given issue. Second, Beiner's and Bernstein's claim that Arendt decided in her later works to formulate judgment as the prerogative of the solitary and contemplating spectator, contradicts and undermines Arendt's understanding of politics as the outcome of collective action among a plurality of individuals. This claim implies that actors in the public space act completely disregarding one another's opinions, as if anarchy is the only rule of conduct. ${ }^{[2]}$ In Arendt's

${ }^{[2]}$ Similarly, Peter Steinberger maintains that relegating judgment "entirely and exclusively to the vita contemplativa" would be to deny that it "plays a crucial role in the vita activa as well" and "to deny this would be, in effect, to deprive action of any mental component, to turn political actors into mindless zombies" (1990: 810). 
account, action and speech are inseparable, and an actor must consider others' opinions insofar as political action entails engaging with them in speech. A form of speech that does not appeal to the opinions of other actors loses its meaning, to the extent that meaning is an intersubjective achievement in the realm of politics. Meaningless speech that does not consider the opinions of others loses its function in the process of opinion formation among a plurality of actors. Thus, rather than being a purely contemplative activity, judging is a mental activity that can never disassociate itself from the realm of public appearances because it takes its bearings from the standpoints of others with whom the judging person constitutes a critical public. As d'Entreves observes with respect to Arendt's conception of judgment as an appropriation of Kantian aesthetic judgment, "individuals have to appeal to the judgments and opinions of others, and thus the validity of their judgments rests on the consent they can elicit from a community of differently situated subjects" (2000: 253).

Although the public dimension of the spectator's judgment in the LKPP links Arendt's earlier and later formulations of judgment, one can still argue that there is an ambiguity in Arendt's theory of judgment with respect to its philosophical sources and its temporal modality. Beiner and Bernstein argue that, in the earlier formulation, Arendt mentions Aristotle's notion of practical reasoning (phronesis) along with Kant's notion of enlarged mentality, while on the other hand in the later formulation, she confines judgment's philosophical source to Kant's notion of aesthetic judgment (Beiner, 1994: 380; Bernstein, 1986: 231). For Bernstein, these different philosophical sources also lead to another problem regarding the temporal modality of judging. When Arendt juxtaposes judgment with phronesis, its temporal modality is that of the future - opinion formation and debate concerns the manner of action that will be taken in the public sphere - whereas when she conceptualizes judging on the model of Kantian aesthetic judgment, its temporal modality becomes that of the past (Bernstein, 1986: 233). Beiner and Bernstein are right in that, in $L K P P$, the spectator's judgment operates retrospectively. Moreover, in the Postscriptum to Thinking, Arendt calls the Homeric historian "the judge" and describes judgment as the faculty whereby we reclaim and win back our human dignity. We can reclaim our human dignity not by "denying history's importance but denying its right to be the ultimate judge" (Arendt, 1992: 5). This is possible only when the historian can look back and judge the meaning that a story reveals at its end (Arendt, 1992: 77). D'Entreves argues that although Arendt's earlier and later formulations do not present an entirely unified theory of judgment, her two different models of judgment are ultimately linked to each other. For him, both Kantian aesthetic judgment and Aristotle's notion of phronesis are "concerned with the judgment of particulars qua particulars, not with their subsumption under universal rules" (d'Entreves, 2000: 253). Furthermore, Arendt's emphasis on exemplary validity in $L K P P$ as the appropriate form of validity that enters into non-cognitive judgments links the temporal modalities of judgment. As d'Entreves explains, Arendt wants this notion of exemplary validity to extend "to events in the past that carry meaning beyond their sheer happening, that is to say, to events that could be seen as exemplary for those who come after" (2000: 251). By culling the meaning of particular events from the past, "the historian or judg- 
ing spectator is able to illuminate their universal import and thereby preserve them as "examples' for posterity" (2000: 251).

The role of the spectator's judgment in preserving for posterity the past deeds in the collective memory of a community also appears in Majid Yar's analysis of Arendt's theory of judgment. Nevertheless, Yar argues that Arendt's two formulations of judgment remain in tension. For him, the fundamental issue is that she addresses "simultaneously not one, but two distinct concepts of action, of the political, and attendant modalities of judgment" (Yar, 2000: 12). A "communicative-accommodational model of action" constitutes the ground for the actor's judgment, whereas an "expressive-agonal model of action" constitutes the ground for the spectator's judgment. While the actor's judgment is oriented towards the future and the achievement of "shared and generally valid understandings on matters of public interest," the spectator's judgment is oriented towards the past and preservation of "the beauty, greatness, or pathos of acts and actors" (Yar, 2000: 12-13). Although Arendt's theory of political action is susceptible to the claim that she addresses two concepts of action, her insistence that the judging spectator is always involved with other spectators with whom she constitutes a critical public; this brings the spectator's judging activity closer to the communicative-associational model of action in Yar's account. It may even be argued that the critical public of judging spectators evaluates and discerns the quality of acts already performed with a view to establishing "shared and generally valid understandings" on these matters as examples for posterity.

Consequently, the public dimension of the spectator's judgment in LKPP establishes a link between Arendt's two formulations of judgment, even if it does not render her scattered remarks on judging entirely coherent. Beiner's and Bernstein's depiction of judgment as the prerogative of a solitary contemplating spectator in Arendt's later formulation overlooks this public dimension of the spectator's judgment. Their interpretation of Arendt's theory of judgment renders the judging activity of the spectator almost indistinguishable from thinking, and as such judging is not consistent with key concepts like plurality and appearance in Arendt's political thought. D'Entreves offers us a more sympathetic reading of Arendt's theory of judgment, in terms of its different philosophical sources and temporal modalities, which both Beiner and Bernstein point out as evidence of fundamental tensions. Yar arrives at a rather different analysis of the tensions in Arendt's theory of judgment by mapping them onto two different concepts of action in Arendt's political thought. However, Yar's distinction between the two modalities of judgment that attend the communicative-associational and expressiveagonal concepts of political action becomes less precise in light of the public dimension of the spectator's judgment, because this aspect of the spectator's judging activity bears close resemblance to the communicative-associational model of action. Thus it is d'Entreves' analysis that comes to the fore as one in which the public dimension of the spectator's judgment is sufficiently recognized. However, d'Entreves' analysis does not provide an explanation for the public dimension of the spectator's judgment except for Arendt's specific appropriation of Kant's aesthetic judgment. As argued below, the public dimension of the spectator's judgment in the LKPP, along with the essentially political character of judging in both the earlier and later formulations, is due primar- 
ily to Arendt's ontology of politics as appearance, and secondarily to her notion of plurality. In arguing that Arendt's earlier and later formulations are ultimately linked together, d'Entreves does not provide an account of Arendt's political ontology, and therefore does not situate the public dimension of the spectator's judgment within the context of Arendt's broader understanding of politics. Arendt's ontology of politics as appearance suggests that both acting and judging entails self-disclosure, and that both the actor and the spectator are meant to see and be seen by others. This implication of Arendt's ontology of politics conveys in turn the idea that the actor and the spectator do not represent mutually exclusive and fixed roles in the public sphere. The following section will discuss these implications of Arendt's ontology of politics as appearance and explain the theatrical character of the public sphere in her thinking.

\section{The Ontological Account of Politics in The Life of the Mind and the Theatricality of the Public Realm}

Arendt's ontological account of politics in her chapter on appearance in The Life of the Mind is one of the least examined aspects of her thought. Arendt maintains that being and appearing coincide, and therefore everything that exists in the world is meant to appear. The world that human beings are born into is a world of appearances, and every individual in this world is a spectacle for others, with others being a spectacle for her. Arendt grounds spectatorship ontologically on the idea that "to be" means "to appear to others," that is, to appear to other spectators. Every individual who is born into the world is a subject and an object at the same time (Arendt, 1981: 19). Arendt calls this idea worldliness and claims that "the worldliness of living things means that there is no subject not also an object and appears as such to somebody else, who guarantees its 'objective' reality" (1981: 19). Hence, for her, our conception of reality is dependent on what we see and what is being seen by others. As Curtis explains it, "Arendt's basic approach to the nature of reality is phenomenal, and the central metaphor that carries the weight of her phenomenological conception is theater" (1997: 38). Thus, from the perspective of Arendt's political ontology, both the actor and the spectator are meant to appear to others, and the roles of the actor and the spectator in the public realm are not mutually exclusive.

For Arendt, every human being in this world has an "urge to self-presentation," meaning that every one of us presents her particular and distinctive personality to others in speech and action as she deems appropriate. ${ }^{[3]}$ We have the capacity to present ourselves to others as we wish rather than only passively appearing to them as we are (Arendt, 1981). This idea of self-presentation is suggestive of Arendt's comment in "The Crisis in Culture" that, while judging, an individual discloses herself to a certain extent in an

[3] This idea of self-presentation in the public realm is analyzed thoroughly in Norma Claire Moruzzi's Speaking through the Mask where she draws "a theory of agency as strategic performance" from Arendt's works. Moruzzi explores the link between questions of social identity and political agency, and argues that in a theory of agency as strategic performance social identity can be understood to be "constructed and strategically performed," hence, "politicized without being essentialized" (2000: 153-154). 
involuntary manner. Although she usually associates self-disclosure with action (1958: 175-181), Arendt also maintains that the partial and involuntary self-disclosure of the agent in judging constitutes the political significance of judgment:

\begin{abstract}
Whenever people judge the things of the world that are common to them, there is more implied in their judgments than these things. By his manner of judging, the person discloses to an extent also himself, what kind of person he is, and this disclosure, which is involuntary, gains in validity to the degree that it has liberated itself from merely individual idiosyncrasies (1993: 223, emphasis added).
\end{abstract}

The partial and involuntary self-disclosure involved in judging suggests that, for Arendt, there is a difference of degree between judging and acting with respect to selfdisclosure. Both activities are oriented towards what is common between individuals in a public realm, and in the performance of both activities, individuals who share the same public space and hence have the same things of the world in common disclose their distinct identities to different degrees.

Self-disclosure entailed in acting and judging is a consequence of appearance as the fundamental ontological condition of being in Arendt's thought. Self-disclosure, whether partial and involuntary or deliberately aimed at, presupposes the existence of other individuals who stand as spectators of the disclosure of the self in acting and judging. In contrast to Beiner's and Bernstein's readings of a solitary contemplating spectator in Arendt's theory of judgment, Arendt's definition of being as appearing in The Life of the Mind has its corollary in the idea in LKPP that spectators can only exist in the plural as a critical public. In Robert Pirro's words, "[t]he fact that plurality conditions spectatorship" is important because "it not only distinguishes the activity of spectatorship from the singularity of philosophic contemplation but also constitutes the ground for spectatorship's fundamental compatibility with the spectacle on which it is directed, human affairs" (2000:128). The spectacle of human affairs ontologically consists of appearances, and the spectator becomes one among many other spectacles the moment she discloses herself in communicating her judgment.

The characterization of the spectator as a solitary contemplating individual also renders her categorically different from the actor. However, in Arendt's account of politics, the spectator is "simply a different mode of relating to, or being in, the common world" (Zerilli, 2005a: 160). This difference between the spectator and the actor, as the difference between two modes of being in or relating to the common world, can be illustrated by the theatrical understanding of politics in Arendt's thought. For her, politics resembles "the performing arts" in the sense that it does not produce an "end product" that remains in existence after politics. In other words, politics is not a work of art, which once produced, exists independent of further action to preserve it (Arendt, 1993: 153). Action, which Arendt defines as the political activity par excellence, realizes freedom as an actuality manifested in "the performing act" (Arendt, 1993: 153). Therefore, for her, freedom constitutes the only product and raison d'être of politics (1993: 146). Arendt illustrates the freedom inherent in the performing act by drawing upon its similarity to virtuosity, which according to her is an excellence attributed to the performing arts (Arendt, 1993: 153). In the performing 
arts and especially in music, we call someone a virtuoso who excels at or devotes special attention to technique in performing. As a virtuoso needs an audience who will recognize her excellence in performing, for Arendt, actors need the presence and recognition of others when acting in the public sphere. These others, to whom the acting individual appears, become spectators so long as they do not act themselves. Therefore, in addition to the phenomenal nature of reality for Arendt, her virtuosity metaphor also conveys that she has a theatrical understanding of the public sphere and politics (Villa, 1999). This theatrical understanding of politics does not deny the actor and the spectator each other's roles, because they represent different modes of relating to the common world. ${ }^{[4]}$ These two roles in the public sphere do not correspond to categorically distinct skills. A spectator, before any other attribute she might have over and above an actor, is uninvolved and detached from the whirl of events taking place in the public realm (Wellmer, 1997: 36). Arendt underlines this idea by saying that "the public realm is constituted by the critics and the spectators, not by the actors and the makers. And this critic and spectator sits in every actor." (1992: 63, emphasis added).

Furthermore, as Pirro suggests, the metaphor of theatre in Arendt's political thought shows how spectatorship provides "redemptive remembrance" for the exercise of freedom, and how in politics one can become accustomed "to look upon the same world from another's standpoint, to see the same in very different and frequently opposing aspects" (2000: 88, 89; Arendt, 1993: 51). The manifestation of freedom in the performance of political action is rescued from oblivion by the recognition and appreciation of spectators, who can reify deeds and words in the form of a story for posterity. Moreover, insofar as the fact of appearance ontologically conditions politics, the theatricality of the public realm in Arendt's thinking suggests that the meaning and reality of political drama can only be established by seeing it from multiple standpoints, that is, by judging.

Consequently, Arendt's ontology of politics and the theatrical character of the public sphere in her thinking suggest that the actor and the spectator are neither mutually exclusive nor substantial and fixed roles. Following Arendt's idea that both acting and judging involve self-disclosure at different degrees, the spectator's limited self-disclosure in judging makes her a spectacle herself. ${ }^{[5]}$ Arendt's theatrical understanding of politics

[4] The degree of disinterestedness required for judgment differentiates the judgment of an actor from that of a spectator. An actor is necessarily an interested person who pursues this interest in action, while a spectator is a disinterested person for she is not interested in what the actor pursues in her action. The spectator is only interested in the meaning of action within a wider web of human relationships. For this reason, one cannot at the same time act in an interested manner and judge in a fully disinterested manner. Yet an acting person can still judge by partially disassociating herself from her private interests in order to engage in an intersubjective discussion with other actors. This willingness to achieve impartiality and communicate on an issue of common concern is the essential condition of differentiating anarchy from group action for Arendt (Arendt, 1979: 310)

[5] The spectator, by judging in a critical public constituted by other spectators, engages in a different form of action. Thus she never leaves the realm of appearances and hence the realm of action. In communicating her judgment to the other spectators, the spectator inserts herself into a web of relationships among spectators and then she becomes an actor on a different stage. The example of Immanuel Kant passing judgment on the meaning of the French Revolution in the LKPP clarifies this point. In one sense, Kant is not an actor. He is not an agent of terror, and even makes clear that, from the perspective of the actors involved, the terror could not possibly be morally justified. However, Kant is an actor in another series of events. He publishes his remarks about the French Revolution in journals read and debated by his contemporaries. His act of judgment is intended for public critique, he is aiming to persuade others of his interpretation of events. 
also brings us to the question of how judging is related to freedom, which constitutes the purpose and meaning of politics for Arendt, and the human condition of plurality, which Arendt defines as the condition that makes politics possible. The next section will analyze the relationships between judgment, freedom, and plurality in Arendt's political thought.

\section{Judgment, Freedom, and Plurality}

Plurality, in Arendt's definition, expresses the idea that every human being born into the world is a distinct and unique person and has the capacity to begin something new. Every individual is both the same as others and irreducibly different from them in having the potential to become a unique person (Arendt, 1958: 175-176). The capacity of each individual to begin something new is actualized in action, and political life is both possible and necessary in the world because it is inhabited by a plurality of human beings (Arendt, 1958: 7, 9). Action would lose its peculiar character without plurality, because, as the activity that takes place directly between individuals, action is the abode of freedom. It is through the freedom actualized in action that each newcomer manifests her uniqueness, and the freedom manifested in the performing act constitutes "the meaning of politics" in Arendt's thinking (Arendt, 2005: 108). For her, plurality is the "conditio per quam of all political life," while freedom in action is the "raison d'etre" of this political life (Arendt, 1958: 7; Arendt, 1993: 153). As Zerilli maintains, in Arendt's political thinking, plurality is far from being a mere state of being or an "ontological condition of human differences" that confronts us. Rather, plurality is a "political relation" that stands in need of creation and actualization. (2005a: 145). Thus, Zerilli defines an active dimension to plurality, that is, the capacity of each individual to begin something new in the world finds its manifestation and actualization in the freedom in action. Zerilli also maintains that human freedom inherent in action is "an artifact of judgment" in the sense that the fleeting character of freedom present in action and the unpredictability that this freedom brings to action are affirmed by judgment as a procedure of dealing with the particular qua particular (2005a: 126-131). Accordingly, the main task or problem of judgment is not some sort of universal validity, rather it is the affirmation of the human freedom in action (Zerilli, 2005a: 131). In this sense, judgment entails "a political concept of validity" that is suitable to a world of appearances inhabited by a plurality of individuals (Zerilli, 2005a: 139). This political form of validity is distinct from the validity of the claims of knowledge and truth on the one hand, and the mere subjectivism of personal beliefs on the other. (Zerilli, 2005: 131). ${ }^{[6]}$ Judgment brings the demand for objectivity together with the recognition of plurality in a unique fashion. It does this by enabling the judging person to see the things of the

\footnotetext{
[6] Arendt's ontological account of politics as appearance prevents her from developing a concept of judgment that entails a universally valid single viewpoint from where we can see all of the multiple aspects of the things of the world. Hence, there cannot be one transcendental truth behind the appearances that judgment would be capable of seizing. Even if there can be one such truth behind the manifold appearances of the world, for Arendt, it would be beyond the political realm as it is rooted in the realm of appearances and it would be irrelevant for politics.
} 
world from multiple perspectives and by foregrounding a care for the world as what we share in common (Zerilli, 2005a: 139). ${ }^{[7]}$ Thus, judgment, by recognizing plurality through its affirmation of the freedom in action as a manifestation and actualization of plurality, transforms the unpredictability of action from something frightening and uncontrollable into a manifestation of the beauty and greatness of action (Zerilli, 2005a: 145). Judgment also reifies action by bestowing meaning upon it as an unpredictable and irreversible, yet beautiful and magnificent existential achievement of human beings.

Zerilli argues that judgment can effectively affirm freedom only when the imagination is at work in judging functions productively, rather than merely reproductively. Productive imagination discovers relations between those appearances that do not have any necessary relations, and thus expands our sense of what is real or communicable (Zerilli, 2005b: 718). Leslie Paul Thiele challenges Zerilli in that foregrounding the productive imagination causes her to lose sight of the role of reflection in judging and to overlook the moral import of judgment. For Thiele, reflection constitutes the actual activity of judging, and it is an act of understanding guided by examples (Thiele, 2005: 707). Examples facilitate persuasion as narrative accountings, and, by virtue of its exemplary validity, judgment "orients one's moral compass" (Thiele, 2005: 710). However, their differences notwithstanding, both Zerilli and Thiele agree that the exercise of judgment affirms freedom in action. Furthermore, Thiele's account of judging through "the crafting or interpreting of narratives" has a morally productive dimension (2005: 707). Judgments grounded in exemplary validity require the judging person to "legitimate her assessments, evaluations, and choices by rendering an account of their development, referencing commonly shared experiences and worthy examples along the way," that is, to justify how she puts her "story in shape" (Thiele, 2005: 711, 707). If this is the case, contrary to Thiele's claim that "selecting the right examples ... is the better part of judgment," examples cannot be right or wrong prior to judging, because this idea suggests that it is not judging but some prior moral criteria that enables one to tell right from wrong (2005: 711). Instead, reflection is morally productive in the sense that it enables us to determine how something is right or wrong in politics. This is why taste judgment, Arendt insists, is politically relevant insofar as it "sets its own limits to an indiscriminate, immoderate love of the merely beautiful" and "takes care of the beautiful in its own 'personal' way and thus produces a 'culture"' (1993: 222-224). This dimension of judgment will be discussed in the section below on the judgment of the spectator, and it will be argued that the judging activity of spectators produces a political culture of taste in the public realm. Before that, the following section will analyze the judgment capacity of the actor in terms of forming and testing opinions through intersubjective dialogue and persuasion within a public sphere.

[7] Dianna Taylor explains a similar connection between judging and plurality in reference to the function of critical thinking performed from an impartial viewpoint. For her, in Arendt's theory of judgment, judging "insofar as it presupposes a critical stance toward prevailing social and political conditions, also creates the dynamic and multiplistic conditions of human plurality" (Taylor, 2002: 164). The function of judging in creating these conditions of human plurality is felt most powerfully in "times of crisis," and this point will be discussed in the section on the judgment capacity of the spectator. 


\section{Judgment of the Actor}

Arendt formulates the judgment of the actor as a procedure of intersubjective opinion formation in the public realm. As such, judging does not proceed from an outside standpoint from where the judging person can see and evaluate an issue in its abstract form. Insofar as this issue is a common concern of those who constitute the public realm, the validity of a person's judgment appeals to how the issue appears to others and how they evaluate it. Thus, judgment consists in a procedure of evaluating a particular qua particular as it is viewed from multiple standpoints, not in a procedure of subsuming a particular under a given universal that exists prior to and independent of the particular. Judgment consists of neither a relativism of "it seems to me" nor a universalism of a truth or knowledge claim. Judgment derives its specific validity from a potential agreement with others, which is a consequence of the "ambiguous connection" of judgment to "the web of human plurality" (Disch, 1994: 141-3). Judgment maintains an ambiguous connection to the plurality of perspectives in the public realm by bringing together the demand for objectivity and recognition of plurality (Zerilli, 2005a: 139-140). Therefore, "a potential agreement with others" with whom the judging person " $m u s t$ finally come to some agreement" requires detachment from individual perspectives and subjective beliefs, a detachment that is short of reaching a universally valid viewpoint outside and above the web of human plurality. Neither does Arendt posit this agreement as a consensus that transcends all disagreement once and for all. ${ }^{[8]}$ Rather, it is situated somewhere between the relativism of continuous disagreement and the universalism of a final consensus. It is a political agreement that plots itself between its temporal and spatial axes. It neither eliminates all disagreement by transcending or subsuming it, nor does it sustain itself by being fixed over time. ${ }^{[9]}$

The presence of others, in whose place a judging person must think, constitutes the spatial limits of the validity of her judgment. ${ }^{[10]}$ Hence, Arendt insists, judgment's "claims to validity can never extend further than the others in whose place the judging person has put himself for his considerations ... it is not valid ... for those who are not members of the public realm where the objects of judgment appear" (1993: 221-2). The representative way of thinking active in judging is strictly bound up in publicity in the sense that, for a person to be able to think in the place of everybody else, the particular standpoints of others should be open to examination. This is possible only when the judging person shares a common public realm with others in whose place

${ }^{[8]}$ The idea of consensus contradicts plurality by not allowing enough room for disagreement and subsumes judgment under the logic of utility.

[9] As the temporal and spatial dimensions constitute it, this political agreement is also an agreement on leaving open the possibilities for perpetual discussion as actors re-form their opinions in a temporal context or as new actors join the discussion. It is different from a continuous disagreement that cannot go beyond mere relativism. Each actor constantly seeks to disassociate herself from her purely private interests and subjective beliefs in order to listen, learn and understand the others and their specific positions. As such, a political agreement is one that is and always will be in a state of becoming.

${ }^{[10]}$ Dianna Taylor argues that the dependence of judgment's validity on the standpoints and opinions of those who are present and share the same public space, distinguishes Arendt's notion of impartiality from Kant's, which is "formal in nature" (Taylor, 2002: 162). 
she must think. The revelation of the unique identity of each individual in speech and action constitutes the primary source of this knowledge of the standpoints of others (Wellmer, 1996: 34). It is only in a web of human affairs consisting of deeds and words that the publicity required for the validity of representative thinking can exist. ${ }^{[11]}$ This sense of publicity is also the source of what Arendt calls common sense. It is the sense that we share with others so long as the world we live in is a common world that lies between us, and it enables individuals to see the issue from the perspectives of others. Common sense, as a community sense ingrained in the web of human relationships, provides the judging person with information about the perspectives of others. ${ }^{[12]} \mathrm{Ar}$ endt defines representative thinking as a political way of thinking because it proceeds through a representation of the standpoints of others in the judging person's mind (1993: 241). Representing the standpoints of others means neither looking at the issue from another person's perspective, nor responding to them with empathy. Instead, it is achieved with the help of what Arendt calls the faculty of imagination. Representing the standpoints of others involves the person imagining how she would feel and think if she was in their place, while remaining in her own standpoint. Disch calls the imagination at work in the process of judgment a "visiting imagination," which provides the imagining person with a situated, as distinguished from an abstract, knowledge that enables her to exercise "principled contextual thinking" (1994: 141, 158). Imagination provides situated knowledge because it is a kind of storytelling, that is, telling "the story of an event from an unfamiliar standpoint." In order to tell the story of an event from an unfamiliar standpoint, one needs to remain in her own identity as the author of the story while imaginatively visiting that position. Disch maintains that the author of the story "can neither stand apart from nor identify with that position" (1994: 158). Hence, Arendt maintains:

This process of representation does not blindly adopt the actual views of those who stand somewhere else, and hence look upon the world from a different perspective; this is a question neither of empathy, as though I tried to be or to feel like somebody else, nor of counting noses and joining a majority but of being and thinking in my own identity where actually I am not (1993: 241).

Thus, judging requires disinterestedness achieved by liberation from one's individual idiosyncrasies, without substituting another person's idiosyncrasies for one's own. Representing the standpoints of others in a disinterested manner is the only way that

${ }^{[11]}$ Iris Marion Young argues that judging should involve more than taking into consideration the perspectives of others with whom we share the same public space. While making our judgments, we should also consider "the collective social processes and relationships that lie between us and which we have come to know together by discussing the world." These collective social processes and relationships create a public world that lies between us as an "objective relation." In this public world, each individual perspective is constituted by relations of privilege and oppression. Judgment as enlarged thought should consider these relations of privilege and oppression in addition to the perspectives themselves. Thus, for Young the publicity required for the validity of the enlarged way of thinking should include the deeds and words in the web of human relationships as well as the objective consequences of these human relationships (2001: 224-25).

${ }^{[12]}$ Similar to the claim made here that the political agreement sought in judging is bounded by both temporal and spatial terms, Peter Steinberger maintains that "the commonness of common sense" is "limited by particular social and historical contexts" because "knowledge-in-judgment is always attached to and dependent upon particular situations" (1990: 814). 
the resulting judgment would be amenable to a potential political agreement. ${ }^{[13]}$ Furthermore, this potential agreement also depends on the number of standpoints represented in the process of judging. The more the represented standpoints, the more general will be the standpoint of the judging person, and hence the higher will be the prospects of potential intersubjective agreement.

Thus, the validity of the actor's judgment is also closely connected with the generation of power as a potentiality that is inherent in the nature of a specific form of collective action. For Arendt, power exists as long as individuals remain together in the manner of acting and speaking together, and "it can only be actualized but never fully materialized," meaning that power needs to be repeatedly actualized in collective action (1958:206). Power requires a form of togetherness that depends on the use of speech to disclose reality, and the use of action to establish new realities (Arendt, 1958:200). Furthermore, the form of collective action that constitutes Arendt's concept of the political is the collective action of individuals, each possessing a unique identity, and each relating to the same issue in a discursive public realm. This common concern appears from a different perspective to each one of the actors since the world that holds them together is a world of appearances where each issue both separates and relates them. Each actor having a distinct standpoint with respect to the issue can only hope to persuade others while she is forming her own opinion on this issue. Therefore, each actor, before acting in a way that will reveal her unique identity, judges the issue in view of a potential agreement with others. The more she liberates herself from private interests, and the more standpoints she imaginatively visits, the higher will be the prospects of persuading others to agree with her opinion. Thus, the political validity of the actor's judgment retains a close relation with the generation of power in collective action. The judgment capacity of the actor enables her to visit the standpoints of other actors each time she inserts herself with her deeds and words into the web of human relationships. In Arendt's thinking, the promise and meaning of politics is freedom (2005: 108), and the freedom that is inherent in political action is an intangible outcome of action's potential to transcend its motives and goals. Freedom is, in a sense, the experience of the new and unexpected that action brings into the human world (Kanuer, 1980: 723). This why Arendt on the one hand insists that action is unpredictable, boundless, and never achieves its purpose, while on the other, defines it as the medium through which human beings can experience freedom. For her, while every actor has the capacity to begin something new or initiate action, for the achievement or completion of the course of action, each actor depends on other actors, who in turn depend on the initiator "for an occasion to act themselves" (Markell, 2006: 4). This mutual dependence of actors on each other constitutes the experience of freedom, "within a political space in the true sense," as a continuous give and take of opinions among a plurality of actors:

\footnotetext{
${ }^{[13]}$ Iris Marion Young argues that we cannot simply represent the standpoints of others by imaginatively taking their positions. This presupposes a symmetrical reciprocity between the subjects. For Young, the positions of different subjects are nonsubstitutable and we can only take the perspective of others into account by listening to them and their specific experiences. Listening to others requires that we should first acknowledge and take into account the other, and then recognize the distinctness of the standpoint of the other in terms of its specific history and social position. Thus, there can only be a relation of asymmetrical reciprocity between subjects constituting the same public space (2001).
} 
The point of the enterprise and of adventure fades more and more, and whereas what before was, so to speak, only a necessary adjunct to such adventures, the constant presence of others, dealing with others in the public space ... now becomes the real substance of a free life. At the same time, the most important activity of a free life moves from action to speech, from free deeds to free words (Arendt, 2005: 124, emphasis added).

Thus, each actor involved in collective action in the public sphere needs to exercise her capacity for judging - considering the viewpoints of others while liberating herself from her private interests - before she can hope for any potential agreement with others on a specific issue. As the actor deals with others and seeks to persuade them in the course of collective action, she discloses a unique identity and appears to others in a specific way. Power springs up between these actors, each engaging with others in words and deeds on an issue of common concern, and, in their efforts to persuade others, actors engage in a continuous intersubjective argumentation of forming, reforming, and negotiating their opinions. Thus, power comes into being as an actuality that contains this ongoing intersubjective argumentation, which occasionally crystallizes into a provisional political agreement.

Consequently, the judgment capacity of the actor is the medium through which the power potential that exists among a plurality of actors transforms itself into an actuality existing in collective action. It functions like a porous screen that delivers what is unique about the actor, while holding back what is merely subjective, hence not fit for public appearance. In this sense, the judgment capacity of the actor preserves plurality as a political relation that "requires that we do something in relation to whatever empirical differences may exist" among us (Zerilli, 2005a: 145). Thus, the actor's judgment affirms plurality as a political relation by fostering the human capacity to begin something new. As a result, the judgment capacity of the actor becomes an essential condition for the "new beginning inherent in birth" to "make itself felt in the world" (Arendt, 1958: 9).

The next section will analyze the judgment capacity of the spectator. It will be argued that the judging spectator's role is essential for preserving plurality in the public sphere, and therefore it does not supplant but supports the judging and performing actor's role.

\section{Judgment of the Spectator}

Analyzing the judgment capacity of the spectator and its function in preserving plurality in the public realm is a more complicated task because Arendt provides us with two different accounts of the spectator's judgment. On the one hand, there is the form of judgment relevant in times of crisis when common sense ceases to function as a guiding thread for judgment and action. On the other hand, there is the form of judgment that operates when common sense and plurality in the public realm are still intact. In general, the judgment of the spectator and the actor are different from each other to the extent that the spectator occupies the position of the uninvolved outsider with respect to particular issues and events in the public realm. Arendt's definition of judgment suggests that a spectator who is not directly related to the object of judgment by virtue of 
being an outsider will be in a better position to judge, insofar as judgment requires the disinterested attitude attained through liberation from private interests and the representation of the object of judgment in one's imagination. Yet Arendt's ontology of politics as appearance suggests that, even as an outsider, the spectator's capacity for judging will be limited. According to Arendt's ontological account, everything that exists in the world appears to a plurality of viewers, and each viewer occupies a particular position with respect to the thing that appears. The spectator, even as an outsider, cannot achieve a full view of the object of judgment for it still appears to her from a partial perspective. For Arendt, in a world of appearances "nothing that appears manifests itself to a single viewer capable of perceiving it under all its inherent aspects" (1981: 38). The manifoldness of appearances in the world suggests that, as is the case in the actor's judgment, the spectator's judgment can only proceed through representative thinking. In $L K P P$, following Kant's aesthetic judgments of taste, Arendt defines judgment as a mental faculty that proceeds through both representative and critical thinking. Arendt follows Kant in defining critical thinking as selbstdenken, that is, thinking for oneself (1992: 43). Arendt maintains that critical thinking, in its Kantian formulation, entails applying critical standards to one's own thought by exposing it to the examination of others in the public realm. Critical thinking requires the presence of others, because, rather than thinking according to certain critical standards, critical thinking means to expose one's judgment to critical evaluation by others. For Arendt, Kantian aesthetic judgment of taste is an appropriate model for political judgment because the products of both art and politics exist essentially as appearances. Hence, the beauty of art objects and the greatness of words and deeds can only be judged by appealing to multiple points of view. In judgments of taste, this appeal to multiple points of view is achieved through representative thinking, and the resulting "impartiality of detached aesthetic judgment guarantees that the object or ground of aesthetic satisfaction will be communicable" (Villa, 1996: 105). Thus, both taste judgments and political judgments are persuasive, and they require an ongoing process of deliberation among a plurality of spectators who see the object of judgment from different perspectives. The representative thinking of the spectator cannot guarantee alone a potential agreement between the plurality of viewpoints on an object of judgment; rather it renders the spectators' opinion fit for public discussion by focusing her attention on the "publicly available aspects of an issue" (Villa, 1996: 105). Thus, in Arendt's thinking, insofar as the deeds and words that constitute the stuff of politics are appearances, the proper criteria by which to judge them is beauty. The spectator can achieve this only by thinking representatively and submitting her resulting opinion to the examination of others who occupy different viewpoints.

The spectator's judgment stands in need of publicity because it proceeds through representative thinking like the judgment of the actor. By virtue of this public dimension, the spectator's judgment constitutes a political culture among spectators sharing the same public realm. Since for Arendt the permanence and beauty of action is judged by the spectators, she grounds her conception of political culture on the idea of taste judgment in Kant's thinking. Arendt appropriates Kant's idea of taste judgment, and applies it to the realm of human affairs as a procedure for discriminating, discerning and 
judging the beauty of political action. This act of discriminating, discerning and judging the beauty of action creates a political culture of taste, and so bestows permanence upon action by providing it with a shared meaning and remembrance. Thus, similar to the validity of the actor's judgment, the validity of the spectator's judgment depends on the potential intersubjective agreement among a plurality of spectators. It is only a potential agreement, rather than a consensus, because the activity of judging reveals to the plurality of spectators, in a process of persuasive exchange and deliberation, what they share in common, and culminates in a political culture of taste. Contrary to Beiner's and Bernstein's account of the spectator as a solitary contemplating person, in terms of Arendt's theory of judgment, the spectator is a non-solitary person who constitutes a public with other spectators. In Arendt's account, the intersubjective nature of the validity of the spectator's judgment generates a political culture of taste that establishes standards for the judgment of action, and provides durability and imperishability for the beauty of action. Therefore, contrary to Beiner's and Bernstein's claim that Arendt locates judgment - as a capacity of the spectator - within the ambit of vita contemplativa, Arendt keeps judgment within vita active, and construes the function of the spectator's judgment as providing critical standards for the durability and imperishability of action. By keeping judgment as a capacity of the spectator within vita activa, Arendt also succeeds in theorizing politics as a separate sphere of human interaction that is an end in itself. In her account, the categories of political thought that guide collective action in the public sphere are products of the political culture of taste shared among the spectators in the same public sphere. Thus, Arendt does not subsume politics under the standards and categories of thought that are beyond politics, and does not theorize politics as a means to a higher end outside itself. In other words, Arendt does not subject vita activa to the standards of vita contemplativa.

However, the political standards and categories of thought break down in times of crisis, when common sense ceases to function as a warning to the faculty of judgment. The public sphere ceases to be a sphere of action and speech, and the standpoints of a plurality of individuals sharing this sphere remain closed to the public view. Thus, common sense loses its character as a community sense that provides judging individuals with information on the standpoints of others. Judgment, as the mental faculty that depends on common sense and proceeds through representative thinking, loses the ground that would constitute its validity. Arendt's conception of times of crisis follows from her views about the unprecedented event of $20^{\text {th }}$ century totalitarianism and its consequences for plurality in the public realm. Totalitarianism, according to Arendt, destroyed the previous categories of thought that enabled human beings to understand the reality of the world and, specifically, of political phenomena. Arendt argues that totalitarianism has "clearly exploded our categories of political thought and our standards for moral judgment" (1953: 379). Totalitarian domination shattered our belief in the adequacy of the traditional mores, customs, or habits to prevent evil from happening, and it even obliterated our capacity for independent thinking and judging (Bernstein, 1997: 317). Accordingly, Arendt thinks of the rise of totalitarianism as a problem of understanding; that is, of reconciling ourselves to the reality of the world in which we live. Since, for Arendt, common sense provides us 
with the reality of the world we live in so long as, between us and others, it is a common world, this sense also enables us to form our categories of moral judgment and political thought (1993: 221). Thus, in times of crisis, when a community loses its sense of reality and its common sense, neither the actor nor the spectator can make accurate judgments because the standpoints of others are no longer accessible and open to examination.

For Arendt, in times of crisis, a different form of the judgment of the spectator comes forth. She explains this form of judgment in terms of Socratic morality which involves a specific kind of critical thinking that can operate even when common sense and plurality in the public sphere are suppressed or eradicated (2003a). In order to think critically, one who lives by the standards of Socratic morality does not need the impetus of reaching an intersubjective agreement. ${ }^{[14]}$ Rather, the Socratic individual occupies a marginal position in the community, and her critical thinking requires only that she does not contradict herself. The judgment of this marginal spectator is oriented towards the self, rather than toward any worldly and public concern. For this reason, the individual who thinks according to the principle of non-self-contradiction does not think and act as a member of the political community. Arendt explains that, for Socrates, it was better to suffer wrong than to do wrong, and it was better to be one within one's self than to live in self-contradiction in order to be in harmony with others (2003a: 181-83). Therefore, the marginal spectator does not think as a citizen (that is, as a person responsible to the whole); rather she thinks strictly for herself, without having a concern for the worldly space between individuals that constitutes a public realm (2003a: 182). Yet in times of crises, when conventional moral standards break down and no longer direct moral behavior, the marginal spectator's care for self-harmony over harmony with others becomes crucially important for preserving plurality in the public realm. For Arendt, "Socratic morality with its negative, marginal qualities" reveals itself as "the only working morality in borderline situations, that is, in times of crisis and emergency" (2003b: 106). At these moments, the critical thinking capacity of the Socratic individual ceases to be a marginal affair for the community because, in circumstances of extreme domination and surveillance, refusing to act according to enforced courses of action becomes a reaction and resistance of central importance for reclaiming plurality in the public sphere. Arendt writes, "when everybody is swept away unthinkingly by what everybody else does and believes in, those who think are drawn out of hiding because their refusal to join is conspicuous and thereby becomes a kind of action" (2003a: 188). These marginal spectators, by virtue of their refusal to join in and move with the unthinking masses, become the manifestations of human plurality. Even if they do not engage in political action, they make human plurality felt in the world by their very existence. Thus, the critical thinking of the marginal spectator, which is a form of judging for one's own self, reclaims the plurality that has been withering away from the worldly space between individuals by enabling the spectator to stand against and away from what is happening in society.

\footnotetext{
${ }^{[14]}$ In "Some Questions of Moral Philosophy," Arendt writes, "the philosopher, who not only thinks but is extraordinarily and in the opinion of many of his fellow citizens inordinately fond of thinking, ... does not examine things in order to improve either himself or others" (Arendt, 2003b: 106).
} 


\section{Conclusion}

This article analyzed the judgment capacities of the actor and the spectator in Arendt's theory of judgment. Against the claim raised by Beiner and Bernstein that, in her later works, Arendt's focus shifted from the vita activa to the vita contemplativa, this article argued that judgment, both as the capacity of the uninvolved and disinterested spectator and the capacity of the engaged actor, serves to preserve the plurality in a discursive public realm. This article showed that considering the spectator's judgment within the ambit of the vita contemplativa, as Beiner and Bernstein do, would disparage the meaning and significance of judging in Arendt's political thought. In either form - as the capacity of the spectator or of the actor - judgment is deeply rooted in the human condition of plurality and in Arendt's ontology of politics as appearance. Therefore, in Arendt's thinking, the proper location of judgment is vita activa, not vita contemplativa, and the judgment of both the actor and spectator are essentially political skills. Furthermore, following from Arendt's ontology of politics as appearance and her theatrical understanding of the public realm, the roles of the actor and the spectator are not mutually exclusive. Instead, being a spectator or an actor are different modes of relating to the common world that holds them together. For this reason, contrary to the position of Beiner and Bernstein, this article argued that these two modes of relating to the world cannot be separated by locating one within the vita activa and the other within the vita contemplativa. The judgment capacities of the actor and the spectator have a complementary function in preserving plurality in the public realm. It is only when plurality is preserved and actualized as a political relation, through the judgment capacities of both the actor and the spectator, that politics as Arendt conceptualizes it can meaningfully be realized in the world.

\section{References}

Arendt, H. (1953). “Understanding and Politics,” Partisan Review, 20: 377-392.

------, (1958). The Human Condition. Chicago. The University of Chicago Press.

-----, (1968). Men in Dark Times. New York. Harcourt, Brace and World.

-----, (1979). “On Hannah Arendt,” in M. Hill (ed.), The Recovery of the Public World: 301-339. New York: St. Martin's Press.

-----, (1981). The Life of the Mind. New York: Harcourt Brace.

-----, (1990). “Philosophy and Politics," Social Research, 57: 72-103.

-----, (1992). Lectures on Kant's Political Philosophy. Chicago: The University of Chicago Press.

------, (1993). Between Past and Future. New York: Penguin.

-----, (2003a). “Thinking and Moral Considerations," in J. Kohn (ed.), Responsibility and Judgment: 159-192. New York: Schoken Books.

-----, (2003b). “Some Questions of Moral Philosophy," in J. Kohn (ed.), Responsibility and Judgment: 49-146. New York: Schoken Books.

-----, (2005). "Introduction into Politics," in J. Kohn (ed.), The Promise of Politics: 93-200. New York: Schoken Books. 
Beiner, R. (1994). "Judging in a World of Appearances: A Commentary on Hannah Arendt's Unwritten Finale," in L.P. Hinchman and S.K. Hinchman (eds.), Hannah Arendt: Critical Essays: 365-388. Albany: State University of New York Press.

Bernstein, R. (1986). "Judging the Actor and the Spectator," in R. Bernstein, Philosophical Profiles: 221-237. Cambridge: Polity Press.

, (1997). “The Banality of Evil' Reconsidered," in C. Calhoun and J. MacGowan (eds.), Hannah Arendt and the Meaning of Politics: 297-322. Minneapolis: University of Minnesota Press.

Curtis, K.F. (1997). "Aesthetic Foundations of Democratic Politics in the Work of Hannah Arendt," in C. Calhoun and J. MacGowan (eds.), Hannah Arendt and the Meaning of Politics: 27-52. Minneapolis: University of Minnesota Press.

D'Entreves, M.P. (2000). “Arendt's Theory of Judgment,” in D. Villa (ed.), The Cambridge Companion to Hannah Arendt: 245-260. Cambridge: Cambridge University Press.

Disch, L.J. (1994). Hannah Arendt and the Limits of Philosophy. Ithaca: Cornell University Press

Isaac, J.C. (1997). Democracy in Dark Times. Ithaca: Cornell University Press.

Markell, P. (2006) “The Rule of the People: Arendt, Archê, and Democracy," The American Political Science Review, 100: 1-14.

Mewes, H. (2009). Hannah Arendt's Political Humanism. Frankfurt: Peter Lang.

Moruzzi, N.C. (2000). Speaking through the Mask: Hannah Arendt and the Politics of Social Identity. Ithaca: Cornell University Press.

Pirro, R. (2000). Hannah Arendt and the Politics of Tragedy. DeKalb: Northern Illinois University Press.

Steinberger, P. (1990). "Hannah Arendt on Judgment," American Journal of Political Science, 34: 803-821.

Taylor, D. (2002). "Hannah Arendt on Judgment: Thinking for Politics," International Journal of Philosophical Studies, 10: 151-169.

Thiele, L.P. (2005). “Judging Hannah Arendt: A Reply to Zerilli,” Political Theory, 33: 706-714.

Villa, D.R. (1999). Politics, Philosophy, Terror: Essays on the Thought of Hannah Arendt. Princeton: Princeton University Press.

------, (1996). Arendt and Heidegger: The Fate of the Political. Princeton: Princeton University Press.

Wellmer, A. (1996). "Hannah Arendt on Judgment: The Unwritten Doctrine of Reason," in L. May and J. Kohn (eds.), Hannah Arendt: Twenty Years Later: 33-52. Cambridge: The MIT Press.

Yar, M. (2000). "From Actor to Spectator: Hannah Arendt's 'Two Theories' of Political Judgment," Philosophy and Social Criticism, 26: 1-27.

Young, I.M. (2001). “Asymmetrical Reciprocity: On Moral Respect, Wonder, and Enlarged Thought," in R. Beiner and J. Nedelsky (eds.), Judgment, Imagination and Politics: Themes from Kant and Arendt: 205-228. Lanham: Rowman and Littlefield Publishers.

Zerilli, L.M.G. (2005a). Feminism and the Abyss of Freedom. Chicago: The University of Chicago Press.

------, (2005b). "Response to Thiele," Political Theory, 33: 715-720. 